\title{
Historyczne uwarunkowania Soboru Stu Rozdziałów
}

\author{
ks. Karol Wilkiel \\ Katolicki Uniwersytet Lubelski, Instytut Ekumeniczny \\ Polska \\ ORCID: 0000-0001-6292-3167 \\ karol.wilkiel@gmail.com
}

rev. K. Wilkiel, Historical conditions of the Stoglavy Synod, Elpis, 21 2019: 27-33.

\begin{abstract}
Artykuł podejmuje historyczne uwarunkowania jednego z ważniejszych soborów, który odbył się w ruskiej cerkwi. Został zwołany przez cara Iwana IV, na początku 1551 r. w Moskwie i przeszedł do historii pod nazwą Sobór Stu Rozdziałów. Nazwa soboru wynika z jego postanowień - dokumentu końcowego, który zawierał sto artykułów (rozdziałów). Niniejszy artykuł ma za zadnie ukazać zawiłości historyczne jakie były obecne w cerkwi na Rusi w XVI w., z których wynikała potrzeba zwołania soboru. Druga część artykułu przedstawia okoliczności otwarcia oraz przebieg obrad soborowych.

Streszczenie: Artykuł podejmuje historyczne uwarunkowania jednego z ważniejszych soborów, który odbył się w ruskiej cerkwi. Został zwołany przez cara Iwana IV, na początku 1551 r. w Moskwie i przeszedł do historii pod nazwą Sobór Stu Rozdziałów. Nazwa soboru wynika z jego postanowień - dokumentu końcowego, który zawierał sto artykułów (rozdziałów). Niniejszy artykuł ma za zadnie ukazać zawiłości historyczne jakie były obecne w cerkwi na Rusi w XVI w., z których wynikała potrzeba zwołania soboru. Druga część artykułu przedstawia okoliczności otwarcia oraz przebieg obrad soborowych.
\end{abstract}

Keywords: The Orthodox Church, history of church, council, Russian Orthodox Church

Słowa kluczowe: Prawosławie, historia kościoła, sobór, Rosyjski Kościół Prawosławny

Jedną z najważniejszych cech, określających istotę Cerkwi prawosławnej jest ,soborowość”. W odczuciu prawosławnego chrześcijanina oznacza ona podstawową zasadę życia Cerkwi. Rangę soborów warunkowały przyczyny ich zwołania: najważniejsze były sobory powszechne, następnie sobory lokalne (których postanowienia wchodzą w skład prawa kanonicznego). Natomiast sobory czy też synody, zwoływane w autokefalicznych Cerkwiach lokalnych, zajmowały się ich sprawami wewnętrznymi (Anchimiuk, 1977, s. 77-79).

Jednym z takich soborów, był Sobór Stu Rozdziałów, który odbył się w Moskwie, w 1551 r. Był to tzw. Sobór Ziemski, ponieważ podejmowane na nim były decyzje nie tylko dotyczące Cerkwi, ale również i państwa. Inicjatorem zwołania Soboru był car Iwan IV Groźny (Florja, 2010, s. $628-629)^{1}$ w porozumieniu z metropolitą moskiewskim Makarym. W soborze uczestniczyli dwaj arcybiskupi, siedmiu biskupów, przedstawiciele monasterów, niższego duchowieństwa, bojarów oraz wiernych. Główną przyczyną zwołania Soboru był nieporządek w liturgicznym i duchowym życiu Cerkwi na Rusi. Po upadku Konstantynopola w 1453 r. władcy Moskiewscy zaczęli postrzegać siebie jako następców bizantyńskich imperatorów. Zwołany przez cara Sobór miał celu ukazanie bizantyńskiej symbiozy państwa i Cerkwi (Bułgakow, 1870, s. 219-220).

Iwan IV Groźny - urodzony 25 sierpnia 1530 w miejscowości Kołomienskoje, zmarł 18 marca 1584 r. w Moskwie. Syn Wasyla III i Heleny Glińskiej. Od 4 grudnia 1533 r. Wielki Książę Moskiewski. Był on pierwszym władcą Rosji, który koronował się na cara. Owo wydarzenie miało miejsce 16 stycznia $1547 \mathrm{r}$. Władzę sprawował do śmierci, tj. do $1584 \mathrm{r}$.

\section{Funkcjonowanie Cerkwi na Rusi w XVI w.}

Funkcjonowanie Cerkwi ruskiej w XVI w. wyrażone jest w dziejach wielu soborów, które zwoływane były w tym okresie. Pozwalały one na podjęcie wielu decyzji dotyczących praktycznie wszystkich aspektów życia Cerkwi prawosławnej na Rusi - poczynając od losów własności ziem do fundamentalnych zasad: pisania ikon, szczegółów liturgicznego aspektu nabożeństw, rozwoju kształcenia szkolnego itd. Ważnym aspektem tego okresu było wznowienie kontaktów z Patriarchatem Konstantynopolitańskim. Kontynuowana była współpraca z monasterami Świętej Góry Atos oraz innymi prawosławnymi centrami duchowymi chrześcijańskiego Wschodu.

Śmierć Wasyla III (Sinicyna, 2004, s. 116-117)² przyniosła zamęt i kilkunastoletni okres walk wewnętrznych na terenie księstwa moskiewskiego. Długo wyczekiwany syn zmarłego władcy miał dopiero trzy lata. Początkowo rządy objęła jego matka - Helena Glińska i pełniła je $\mathrm{z}$ utworzoną w tym czasie radą regencyjną. Był to czas, który sprytnie wykorzystała stara arystokracja, podejmując próby przejęcia władzy czy chociaż zapewnienia sobie jak

\footnotetext{
2 Wasyl III Ioanowicz (ros. Василий III Иванович) - Urodzony 25 marca 1479, zmarł 4 grudnia 1533. Wielki książę moskiewski w latach 1505 1533. Niemal połowę swojego życia spędził na tronie moskiewskim. Przodkowie pozostawili mu w spadku zadanie doprowadzenia do końca procesu zjednoczenia ziem ruskich oraz umocnienia wywalczonej już niezależności od Tatarów. Władca w ciągu zaledwie 15 lat doprowadził do likwidacji samodzielności Pskowa, Riazania, księstwa nowogrodzko-siewierskiego; w trakcie wojen z Litwą zdobył Smoleńsk itd.
} 
największych wpływów na rządy oraz powiększenia swoich majętności poprzez przejmowanie ziem państwowych.

Dwaj bracia Wasyla III - Jerzy i Andrzej starali się bardzo intensywnie zdobyć tron, jednakże rządząca wtedy regencja do tego nie dopuściła. Obydwaj bracia zostali skazani na karę więzienia, gdzie zakończyli swoje ziemskie życie. Dalej wszystko odbywało się bez większych problemów aż do 1538 r., kiedy to umiera Helena Glińska. Przyczyną jej śmierci najprawdopodobniej było otrucie. Od tej pory o władzę w księstwie walczyły dwa bojarskie klany: Szujskich i Bielskich. W takich warunkach wychowywał się Iwan IV, o którego nikt specjalnie nie dbał. Bojarzy, mając nadzieję, że ich władza będzie trwała niezmiennie, lekceważyli i poniżali Iwana. Początkowo przewagę mieli Szujscy. Iwan Bielski został skazany na więzienie, a jeden z członków stronnictwa Bielskich - diak Fiodor Miszurin (jeden z zaufanych doradców Wasyla III), został ścięty bez wyroku sądu, jakiegokolwiek przesłuchania czy też procesu. Metropolita Daniel w tej walce stanął po stronie Bielskich, za co został zdjęty z katedry w $1539 \mathrm{r}$. i zesłany do Wołokołamskiego monasteru, gdzie przeżył jeszcze 8 lat (Sinicyna, 2004, s. 116-117).

Jego następca metropolita Joasaf na tronie zasiadał tylko przez 3 lata. Po kilku miesiącach od wyboru okazało się, że nowy metropolita przeszedł do ugrupowania Bielskich, a więc również był niewygodny dla bojarów będących bliżej władzy. Udało mu się jednak wpłynąc na to, aby uwolniono Iwana Bielskiego i innych członków rodu Bielskich, co w konsekwencji spowodowało, iż uzyskali oni przewagę na dworze. Nie trwało to długo, ponieważ już w 1542 r. Iwan Szujski przybył potajemnie do Moskwy ze spiskowcami i grupą wojska, aby rozprawić się z politycznymi przeciwnikami. Bielski trafia ponownie do więzienia, jednakże tym razem nie udało mu się już wyjść na wolność. Członków stronnictwa Bielskich wyłapywano systematycznie, a z katedry zdjęty został metropolita Joasaf, jako wróg polityczny. Te krwawe walki o władzę między bojarami odbywały się na oczach młodego księcia. W historiografii powszechnie mówi się, iż to, czego doświadczył w młodości, wpłynęło na psychikę i charakter Iwana IV, który podczas swojego dzieciństwa był bardzo upokarzany przez bojarów i na własne oczy widział mnóstwo strasznych scen. Prawdopodobnie była to jedna z głównych przyczyn tego, iż stał się on największym w dziejach Rosji okrutnikiem i w ramach odwetu po latach krwawo rozprawił się z bojarstwem. Stąd wziął się jego przydomek - „Groźny” (Serczyk, 2004, s. 4-16; Bazylow 2006, s. 72-73; Kartaszew 1959, s. 421-424).

Następcą metropolity Josafa został dotychczasowy abp Nowogródzki - Makary. Arcybiskup Makary został wybrany 16 marca 1542 r. Intronizacja na katedrę Metropolity Moskiewskiego miała miejsce 19 marca 1542 r. W osobie nowo wybranego zwierzchnika Cerkiew otrzymała pasterza, który był w stanie sprzeciwić się zamieszaniu, jakie zaistniało podczas panowania bojarów. Jedną z jego najważniejszych misji była niezależność Cerkwi od Państwa na Rusi. W tym celu zwołano dwa Sobory - $1547 \mathrm{r}$. i 1549 r., podczas których kanonizowano wielu świętych
Cerkwi Ruskiej, co bez wątpienia wzmocniło jej autorytet (Sinicyna, 2000, s. 74; Trubaczew, 2000, s. 349-350).

Współpraca na linii Carstwo - Cerkiew, za panowania metropolity Makarego była najbardziej rozwinięta w historii. Metropolita dokładał wszelkich starań, aby ustabilizować sytuację władzy państwowej. Ważnym krokiem w tym kierunku była przeprowadzona z inicjatywy zwierzchnika Cerkwi koronacja Iwana IV na cara, która miała miejsce 16 stycznia 1547 r. Wydarzenie to nie tylko potwierdziło jego wielkość jako potężnego władcy, równego bizantyńskim imperatorom, ale również wpłynęło na postrzeganie Moskwy jako centrum prawosławnego świata. Ową koronacją ograniczone zostało również znaczenie bojarów i książąt w sprawach zarządzania państwem.

Zanim udało się podjąć stosowne kroki ku poprawie polityki wewnętrznej, w czerwcu 1547 r. w Moskwie wybuchło powstanie. Gniew narodu skierowany był przeciwko zajmującym wysokie stanowiska państwowe krewnym cara ze strony matki - rodowi Glińskich. Oskarżano ich o cztery fale pożarów, które przeszły przez Moskwę. Ogień zajął również zabudowania kremla. Spłonęły trzy sobory, dwa pałace, skarbiec, pokrycia dachowe na Soborze Zaśnięcia Przenajświętszej Bogurodzicy. Podczas tych strasznych wydarzeń, o mało co życia nie stracił metropolita Makary, ratując cudowną ikonę Matki Bożej. Rozdrażniony thum powstańców (wśród których byli w większości pozbawieni majątku pogorzelcy), znalazł ofiary i czekał tylko na sposobność dokonania egzekucji. Na placu wśród tłumu stał wuj cara - Jerzy Gliński, którego rozpoznano i ukamienowano. W tym czasie śmierć poniosło również wielu dworzan, służby i współpracowników Glińskiego. Gdy w mieście nie było już nikogo z ich rodziny ani otoczenia, zażądano od cara, aby wydał swoją babkę Annę i jej syna Michała. Władca stracił wtedy cierpliwość i kazał wojsku rozgonić tłum, przywódców zamieszek najpierw uwięzić, a później stracić (Smirnow, 1944, s. 26-27).

Powstanie moskiewskie 1547 r. nabrało rozgłosu w całym kraju. Niewątpliwie przyczynili się do tego m.in. sami uczestnicy buntu, którzy przerażeni konsekwencjami, jakie spadły na nich, rozproszyli się po innych miastach. Lokalne zamieszki wybuchły w Nowogrodzie i Pskowie. Bez wątpienia źle świadczyło to o stanie wewnętrznym państwa. Trudna sytuacja wymagała rozważnych poczynań. Walka ze zbuntowanym narodem wyłącznie za pomocą środków militarnych prowadziła jedynie do krótkotrwałego przytłumienia objawów. Nie spowodowała jednakże zmiany nastrojów ludu ani tym bardziej ustania przyczyn rebelii. Reformy stały się konieczne (Serczyk, 2004, s. 24).

Po upadku powstania moskiewskiego $1547 \mathrm{r}$. nastąpiły poważne zmiany w składzie najbliższego otoczenia władcy. Chociaż do Dumy Bojarskiej włączona została liczna grupa nowych ludzi, to nadal stare rody zachowywały swoją uprzywilejowaną pozycję. Wyłączenie ich z czynnego życia politycznego odbywało się nieprzerwanie, lecz powoli. Zwiększenie liczebności Dumy Bojarskiej było pierwszym krokiem Iwana IV w walce $\mathrm{z}$ oligarchiczną opozycją. Około czterdziestoosobowa grupa nie była zbyt sprawnym organem władzy, nawet w sytuacji, gdy ich za- 
danie polegało zasadniczo na udzielaniu rad i wskazówek. Na przełomie lat 40. i 50. XVI stulecia, w ramach Dumy Bojarskiej utworzony został zespół zaufanych doradców, tzw. Duma Bliższa (Bliżniaja Duma). Skład jej zmieniał się nieustannie i przewinęło się przez nią, co najmniej kilkanaście osób. Niezmiennym jej członkiem był Aleksy Adaszew - syn bojarski z Kostromy - kierujący jej pracami. Bliskim współpracownikiem cara był również protopop Sylwester (kapłan Soboru Zwiastowania Przenajświętszej Bogurodzicy na Moskiewskim Kremlu), jednakże jako duchowny nie wchodził formalnie w skład grupy rządzącej. Odgrywał on jedynie rolę czołowego ideologa i pomysłodawcy owego ciała zarządzającego (Florja, 2010).

Połowa XVI w. związana jest ściśle ze zwołaniem pierwszych ziemskich Soborów. Sobór Stu Rozdziałów, którego dotyczy niniejszy artykuł, był również soborem ziemskim, dlatego postaram się przeanalizować ową nazwę. W źródłach pochodzących z XVI w. termin „sobór ziemski" nie jest spotykany. Nazwa ta jest pojęciem wypracowanym przez historyków rosyjskich żyjących w XIX w., w celu jego odróżnienia od cerkiewnego tzw. „Oświęconego Soboru". Wcześniej używano naprzemiennie nazw „sobór” lub „zgromadzenie”. Słowo „ziemski” w XVI w. oznaczało - państwowy. Stąd sprawy ziemskie były sprawami całego państwa. Z kolei słowo „Sobór” związane było z jednostką zarządzającą w Cerkwi Prawosławnej. W skład członków Soboru ziemskiego wchodzili członkowie Świętego Soboru Ruskiej Cerkwi, przedstawiciele Dumy Bojarskiej, wojewodowie oraz przedstawiciele szlachty (Czerepnin, 1978, s. 63-67).

Pierwszy Sobór ziemski zwołany został 27 lutego 1549 r. w pałacu carskim. Uczestniczyli w nim członkowie Świętego Synodu Cerkwi na czele z metropolitą Makarym, członkowie Dumy Bojarskiej oraz reprezentanci szlachty. Nie było na nim jednak przedstawicieli mieszczaństwa. Obrady trwały dwa dni. Car przemawiał trzykrotnie. Przedstawił on program zażegnania kryzysu politycznego oraz wprowadzania reform w państwie. Oskarżył on również bojarów o nadużycie władzy oraz o to, że wiele nieprawości działo się w czasie, kiedy był jeszcze małoletni. Car zagroził, że w przypadku powtarzalności takiej sytuacji będą stosowane bezwzględne kary.

Słowa cara przestraszyły bojarów, spodziewających się krwawych represji. Zaczęto więc prosić monarchę, aby w przypadku wpłynięcia konkretnych skarg, sprawy były kierowane na drogę sądową. Ku zdziwieniu wszystkich Iwan IV, obiecał, że nie ukarze bojarów za ich wcześniejsze postępowanie, jednocześnie wzywając wszystkich będących $w$ jego otoczeniu do pojednania. W związku ze wspomnianą ugodą sobór nazywany jest „Soborem pojednania”. Owo zgromadzenie podjęło również decyzję o przygotowaniu nowego wydania Sudiebnika ${ }^{3}$, który miał zastąpić ten wydany w 1497 roku (Andrusiewicz, 2004, s. 369). Nowy zbiór praw ogłoszony był w czerwcu $1550 \mathrm{r}$. Opracowanie nowego wydania było koniecznie, z powodu

\footnotetext{
Sudiebnik - zbiór praw obowiązujących na Rusi, dokładnie regulujących prawo państwowe, administracyjne i cerkiewne.
}

zmiany sytuacji społeczno-politycznej na Rusi. Nowy Sudiebnik przedstawiał m.in. cel i charakter reform, których przeprowadzenia podjął się Iwan IV Groźny (Pawłow i Perrie, 2008, s. 82-84; Czerepnin, 1978, s. 68-78; Serczyk, 2004, s. 30).

\section{Przyczyny zwolania Soboru Stu Rozdziałów}

Sobór, który odbył się w 1551 r., przeszedł do historii pod nazwą Stogławyj Sobor, ponieważ jego postanowienia - dokument końcowy zawierał sto artykułów (rozdziałów). Celem cara była sekularyzacja Cerkwi, tj. ograniczenie jej roli w państwie do minimum oraz przejęcie majątku cerkiewnego przez władze świeckie. Jednym z najbardziej skomplikowanych problemów, jakimi zajmował się Sobór była sprawa ujednolicenia obrzędów i rytów cerkiewnych na terenie całego cesarstwa. Wspomniane wcześniej działania reformatorskie cara Iwana IV Groźnego dotyczyły głównie państwa. Wydanie nowego Sudiebnika, a więc zmiany w systemie sądownictwa oraz administracji, miały znaczący wpływ na osłabienie bojarstwa, a jednocześnie likwidację jednego z najbardziej uciążliwych reliktów minionego okresu. Kiedy praca ta została zakończona, car wyraził chęć wdrożenia reform, mających na celu poprawę cerkiewnej egzystencji. W związku z tym, na początku 1551 r., zwołuje w Moskwie Sobór, określany przez Makarego Bułgakowa (1870), jako „najważniejszy spośród wszystkich soborów, jakie miały miejsce dotychczas w Cerkwi ruskiej” (Bułgakow, 1870, s. 219).

Jedną z przyczyn zwołania soboru była próba ograniczenia własności cerkiewnej, na którą złożyło się wiele czynników. Po pierwsze - brak ziem, które można byłoby rozdysponować. Drugim czynnikiem było to, iż władza miała możliwość efektywnego funkcjonowania, wówczas, gdy z trzech obecnych wówczas sił politycznych: szlachty, bojarów i Cerkwi (branych pod uwagę jako ewentualnych sojuszników), nie tylko wybrano by jedną, a jednocześnie usunięto by dwie pozostałe. Polityka cara, która skierowana była przeciwko bojarom, wskazywała na zamiar usunięcia ich z obecności w życiu politycznym. Kolejna siła polityczna - szlachta - obdarzana była przywilejami. Pozostawała Cerkiew. Jakiekolwiek działania wymierzone w religię, nie mogły być, i nie były brane pod uwagę. Próbowano jednak pozbawić Cerkwi znaczenia w sferze politycznej. Cel ten mógł być wykonany poprzez pozbawienie jej gospodarczych podstaw działania, a więc dóbr materialnych (Kartaszew, 1959, s. 433-435). W związku z tym car oczekiwał od soboru oddania monasterskich oraz cerkiewnych majątków nieruchomych na rzecz potrzeb państwowo-społecznych. Owe potrzeby wynikały z konieczności zabezpieczenia finansowego zwiększającego się liczebnie wojska (Serczyk, 2004, s. 32). Cara, w jego zamiarach,

\footnotetext{
Mowa jest tutaj o stałej armii (formacji strzelców), którą Iwan IV powołał do życia w 1550 r. Nowy typ wojska opłacanego bezpośrednio ze skarbu państwa, żołnierza „zawsze gotowego”, pozwalał monarsze na swobodniejsze niż dotychczas manewry zarówno w polityce zagranicz-
} 
poparła partia niestiażatielej. W radzie rządzącej jedną z czołowych ról odgrywał pewien człowiek imieniem Sylwester, który mocno związany był ze wspomnianym ruchem, przeciwnym posiadaniu przez monastery i struktury cerkiewne majątków. Sylwester nie tylko nie wyraził sprzeciwu w sprawie sekularyzacji dóbr cerkiewnych, lecz przeciwnie, najprawdopodobniej nakłaniał władcę do poczynań idących w tym kierunku (Kartaszew, 1959, s. 434-435; Sawicki 2012, s. 38). Problem był dość zawiły. Państwo nie mogło liczyć na dobrowolne ustępstwa ze strony Cerkwi. Pierwsze konsultacje przeprowadzone na ten temat z metropolitą Makarym doprowadziły do stanowczego sprzeciwu ze strony zwierzchnika Cerkwi. Swoją dezaprobatę wyraził on w piśmie skierowanym do cara, zatytułowanym: Odpowiedź o nieruchomych dobrach, danych Bogu jako dziedzictwo wiecznych dóbr. W owej odpowiedzi metropolita cytuje postanowienia soboru $1503 \mathrm{r}$., w obronie praw majątkowych Cerkwi, a następnie w bardzo dobitny sposób wyraża swe oczekiwanie wobec cara co do przestrzegania owych praw. Ostatecznie przyjęto rozwiązanie kompromisowe, które zabraniało zakładania nowych gospodarstw na terenie dóbr monasterskich. Zabroniono również przyjmowania uchodźców z miast do pracy w gospodarstwach monasterskich. Kwestia najważniejsza, a mianowicie sekularyzacja dóbr cerkiewnych nadal pozostała nierozwiązana. Władze cerkiewne miały świadomość tego, że wobec stałego wzrostu bogactwa w strukturach cerkiewnych, sprzeciw może nastąpić nie tylko ze strony rządu centralnego, ale również ze strony wiernych, a także ze strony prawowiernych mnichów, obserwujących z niepokojem zwiększające się zainteresowanie biskupów dobrami doczesnymi, a jednocześnie zaniedbywanie spraw cerkiewnych (Kartaszew, 1959, s. 435).

Analizując przyczyny zwołania Soboru Stu Rozdziałów, należy powrócić do idei Moskwy jako trzeciego Rzymu. Po upadku Konstantynopola w 1453 r. władcy Moskiewscy zaczęli postrzegać siebie jako następców bizantyńskich imperatorów. Uważano, że cesarstwu Rzymskiemu, w którym urodził się Jezus Chrystus, dane jest istnieć na Ziemi do końca świata, aby było ono strażnicą Kościoła Chrystusowego. Zgodnie z logiką tej idei jego stolica początkowo znajdowała się w starożytnym Rzymie, następnie przeniesiona została do tzw. drugiego Rzymu Konstantynopola i ostatecznie po przejęciu Konstantynopola przez Turków w 1453 r., jego centrum stała się Moskwa. Starzec Filoteusz głosił, iż Moskiewski władca jest ,jedynym i prawdziwym na całej ziemi chrześcijańskim carem" (Tryczyk, 2009, s. 170). Dla carstwa ruskiego stanie się trzecim prawosławno-chrześcijańskim cesarstwem było zadaniem trudnym i odpowiedzialnym, zaś dla Cerkwi ruskiej oznaczało zajęcie pierwszego miejsca wśród pozostałych Cerkwi lokalnych. Ta szczególna rola prawosławia na Rusi akceptowana i popierana była-również przez kraje sąsiednie. Od momentu koronacji Iwana IV i przyjęcia ty-

nej, jak i wewnętrznej, gdyż ewentualna niechęć opozycji do jego poczynań nie odbierała mu możliwości realizacyjnych. Wierne wojsko było już teraz zawsze pod ręką. Żołd takiego żołnierza wynosił 4 ruble rocznie. tułu cara, państwo Moskiewskie formalnie zajęło miejsce i przejęło prawa trzeciego rzymskiego carstwa, pozostając jedyną strażnicą czystości prawosławia (Szpakow, 1903, s. 3-6; Sawicki, 2013, s. 52; Stempa, 2016, s. 36-41). Wewnętrzny stan ruskiej Cerkwi musiał odpowiadać teraz pozycji, którą zajęła ona na skalę zewnętrzną. Aby do takiej symfonii doprowadzić, wewnętrzny stan Cerkwi należało poprawić. Służyły temu m.in. sobory 1547 r. i 1549 r., podczas których kanonizowano dużą liczbę świętych. W 1551 r. car, niewątpliwie pod namową metropolity Makarego, zdecydował się na zwołanie wielkiego soboru, który miał na celu oczyszczenie Cerkwi ruskiej z wszelkich obecnych w niej wad i niedostatków. Celem Soboru było również poprawa i aktualizacja jej funkcjonowania w każdej dziedzinie oraz ujednolicenie obrzędów cerkiewnych, które na terenie Rusi często bardzo różniły się od siebie (Szpakow, 1903, s. 8-9).

\section{Otwarcie oraz przebieg Soboru Stu Rozdziałów}

Pierwsze słowa Stogława $a^{5}$ są następujące:

W roku $7059^{6}$ miesiąca lutego, 23 dnia, dane zostały liczne pytania i odpowiedzi dotyczące różnej rangi spraw cerkiewnych, w carskim mieście Moskwie, w carskich pałacach, ot władcy, cara i wielkiego księcia Iwana Wasylewicza, dla najprzewielebniejszego Makarego, metropolity Moskiewskiego i Całej Rusi oraz dla całego Świętego Synodu, w osiemnastym roku panowania cara, dwudziestym pierwszym roku od jego narodzenia, przy najprzewielebniejszym Makarym, metropolicie Moskiewskim i Całej Rusi, w dziesiątym roku jego bycia na tronie (Stoglaw, 1862, s. 19.)

O jakiej dacie jest mowa w powyższym cytacie? Niektórzy historycy twierdzą, iż jest tutaj mowa o dokładnej dacie rozpoczęcia Soboru (Kartaszew, 1959, s. 435-436; Boczkarew, 1906, s. 10-11). Inni badacze tego tematu, jak np. D. Stefanowicz, iż wspomniana data 23 lutego, nie była dniem otwarcia soboru, a redakcji postanowień soboru Stogława. Według niego, prace soboru trwały już na przełomie stycznia i lutego, jak również kontynuowane były po wspomnianej w pierwszych słowach postanowień dacie (Stefanowicz, 1909, s. 81-90). Trudnym zadaniem jest dokładne określenie w czasie zarówno momentu rozpoczęcia, jak i zakończenia działalności Soboru. Można jednak określić dwuetapowość jego prac. Pierwszym etapem były obrady, podczas których omawiano przedstawione wcześniej carskie pytania (ros. царские вопросы). Drugim etapem było zredagowanie materiałów wypracowanych na owych spotkaniach. Najprawdopodobniej obydwa wspomniane procesy odbywały się $\mathrm{w}$ tym samym czasie. Na podstawie tego można wnioskować, iż data 23 lutego 1551 r., to dzień

Stogław - księga zawierająca dziej oraz postanowienia (kanony) Soboru Stu Rozdziałów.

6 Rok podany jest od stworzenia świata. Według wyliczeń, które wykonane zostały z rodowodów, podanych w Starym Testamencie, Chrystus narodził się 5508 lat od stworzenia świata. 
rozpoczęcia Soboru. Wcześniej musiały się rozpocząć prace przygotowawcze (redakcja carskich pytań), co trwało około dwóch miesięcy - stycznia i lutego (Czerepin, 1978, s. 79).

Świadectwa o terminie otwarcia Soboru, o tym, kto brał w nim udział, o przyczynach i celach jego zwołania, zawarte są w czterech pierwszych rozdziałach (gławach) postanowień. Na temat intencji cara co do zwołania Soboru w Stogławie czytamy:

„On, pokój czyniący, możnowładny autokrata, wielce dobry car Iwan, który wielkością rozumu i mądrością był koronowany, i w doskonałej pobożności carstwo swoje utrzymuje, otaczany łaską Ducha Świętego, swoje starania kierował nie tylko w stronę uporządkowania spraw ziemskich, ale również różnorodnych cerkiewnych reform, i ogłasza Ojcu swojemu najprzewielebniejszemu Makaremu, Metropolicie Całej Rusi, aby jak najszybciej zwołać sobór sług Bożych" (Gława II, Stoglaw, 1862, s. 23-24).

W dalszych słowach drugiego rozdziału czytamy, iż na zaproszenie cara do Moskwy jak ,„...] unoszące się z lekkością ku górze orły" (Stoglaw, 1862, s. 24) przybyli wszyscy hierarchowie będący w jurysdykcji metropolii. Byli to biskupi: nowogródzki Teodozjusz, rostowski Nikandr, suzdalski Trifon, smoleński Gurij, riazański Kasjan, twerski Akacjusz, biskup Kołomyi Teodozjusz, Sarowa Sawa oraz Permu Cyprian. Na sobór przybyli oni razem z archimandrytami, ihumenami, starcami, pustelnikami i dużą liczbą duchowieństwa pozostałych godności. Uczestnikami soboru byli również przedstawiciele władzy świeckiej, tj. dumy bojarskiej (Stoglaw, 1862, s. 19).

Sobór rozpoczął się 23 lutego 1551 r. uroczystym Molebniem (Smykowska, 2008, s. 53) 7 Soborze Zaśnięcia Przenajświętszej Bogurodzicy na Moskiewskim Kremlu. Następnie wszyscy uczestnicy przeszli do carskich pałaców. Car zasiadł na swoim tronie, wszyscy pozostali również zajęli swoje miejsca. Gdy nastała cisza i wzrok każdego skupił się na osobie władcy, imperator wstał i przemówił następującymi słowami:

„Proszę was, świętobliwi ojcowie moi, jeśli otrzymałem łaskę przed wami, okażcie mojej osobie waszą miłość, jak na swoim synu, i nie leńcie się przed jednogłośnym wypowiedzeniem słowa o wierze naszej prawosławnej, jak również o stałości świętych Bożych Cerkwi, o naszym bogobojnym carstwie oraz o ukształtowaniu całego prawosławnego chrześcijaństwa. W pełni pragnę i z radością wyrażam zgodę na to, aby stać się wspólnie z wami posługującymi obrońcą wiary, ku chwale świętej współistotnej i nierozdzielnej Trójcy, Ojca i Syna i Ducha Świętego, ku czci naszej pobożnej wiary i cerkiewnej reguły. W związku z tym nakazuję, aby od tej chwili odeszły od nas wszelkie różnice zdań i poglądów, i umocniły się wśród nas zgoda i jednomyślność" (Gława II, Stoglaw, 1862, s. 25-26).

Po wygłoszeniu owego wstępu car przedstawił wszystkim „tekst napisany własnoręcznie (своея руки писание)”

Molebien, czyli modlitwa błagalna, to krótkie nabożeństwo błagalne lub dziękczynne, celebrowane w różnych intencjach, jak również w szczególnych okolicznościach, np. w czasie klęsk żywiołowych.
(Stoglaw, 1862, s. 26), który odczytany został na głos. Tekst ten nie był odczytany przez cara, lecz przez kogoś z uczestników Soboru, najprawdopodobniej przez metropolitę Makarego. W słowie tym Iwan IV, w imię Boga w Trójcy Osób, Przenajświętszej Bogurodzicy i wszystkich świętych (szczególnie tych związanych ziemią ruską), ponownie prosił zebranych pasterzy Cerkwi o podjęcie trudu umocnienia prawdziwej wiary chrześcijańskiej, mającego na celu poprawę cerkiewnego pobożnego porządku, carskiego przestrzegania prawa oraz wszelkiego zarządzania ziemskiego. Władca wzywał do pokuty nie tylko duchownych, ale również książęta, bojarów, żołnierzy i wszystkich prawosławnych chrześcijan. Nawoływał on, aby wszyscy razem z nim nawrócili się na drogę życia w cnotach chrześcijańskich. W tym celu przytaczał przykłady (dawne oraz współczesne) strasznych kar, jakie Bóg posyłał za grzechy. Ze łzami w oczach wspominał o: śmierci swoich rodziców, zabójstwach wujów, samowoli i złej władzy bojarów, którzy zarządzali państwem, swoim sierocym dzieciństwie, w którego czasie doznał wiele lekceważenia ze strony otaczających go ludzi, o karach (a zwłaszcza pożarach w 1547 r.), jakimi Bóg pokarał Moskwę za nieprawości. Następnie Iwan IV powiedział:

Strach ogarnął moją duszę, przerażenie weszło w moje kości i uniżył się mój duch, gdy strapiony ujrzałem moje grzechy. Pośpieszyłem do Świętej Cerkwi i poprosiłem od was hierarchów, błogosławieństwa oraz odpuszczenia moich złych uczynków, a według waszego błogosławieństwa wybaczyłem podwładnym mi bojarom ich przewinienia, które popełnili wobec mojej osoby i rozpocząłem zgodnie z waszą dobrą wskazówką, budowanie i zarządzanie powierzonym mi przez Boga carstwem (Gława III, Stoglaw, 1862, s. 37).

Wyrażając nadzieję na Boże miłosierdzie, car kontynuował:

Wy, ojcowie nasi, pasterze i nauczyciele, prosząc o pomoc wszechmogącego Boga, pouczajcie i oświecajcie mnie, syna swego, braci moich, książęta, bojarów, całe prawosławne chrześcijaństwo, starannie i nieopieszale nauczajcie i umacniajcie, aby wszyscy chronili prawdziwą chrześcijańską naukę. Przede wszystkim oświećcie i umocnijcie się sami (biskupi i kapłani, przyp. aut.) i rozmnażajcie dany wam przez Boga talent, abyśmy my - wszyscy wierni - widząc wasze dobre uczynki i przyjmując wasze duchowe wskazówki, nawrócili się na drogę prawdziwej pokuty i otrzymali miłość od Boga tutaj na ziemi i w przyszłym wieku. Teraz proszę was, zebrany za sprawą łaski Bożej Sobór, w imieniu Boga, Przenajświętszej Bogurodzicy oraz wszystkich świętych, trudźcie się dla nieskalanej prawosławnej wiary, umocnijcie i objaśnijcie, tak jak przekazali nam Święci Ojcowie, zgodnie z Boskimi regułami. [...] Jeżeli przez waszą opieszałość, wyjdzie na jaw jakiekolwiek naruszenie Boskich reguł, ja nie będę miał z tym nic wspólnego, a wy będziecie za to sądzeni przed Bogiem. Jeżeli ja będę się wam sprzeciwiał i występował przeciwko Boskim regułom, wy wtedy nie milczcie; jeżeli będę nieposłuszny, pochwyćcie mnie, bez żadnego strachu, aby żywa była moja dusza oraz aby bez skazy była pra- 
wosławna chrześcijańska nauka i niech święci się Przenajświętsze Imię Ojca i Syna i Świętego Ducha (Gława III, Stoglaw, 1862, s. 41-42).

Ostatnie zdania III rozdziału Stogława mówią o tym, że po zakończeniu mowy cara wszystkich ogarnęło zdziwienie. Uczestnicy Soboru składali Bogu dziękczynienie, a nawet płakali ze szczęścia, widząc takie zatroskanie cara dobrem Cerkwi prawosławnej (Stoglaw, 1862, s. 42; Bułgakow, 1870, s. 222-223).

Kolejna wypowiedź napisana przez cara dotyczyła zreformowanego przed zwołaniem Soboru Stu Rozdziałów prawa zawartego w Sudiebniku. IV Gława poświęcona jest w całości sprawom państwowym. Najprawdopodobniej nie tylko ze względu na uprzejmość władcy, ale przede wszystkim przez jego świadomość - od czasu koronacji na cara - bliskiej współpracy Cerkwi z państwem (na wzór Bizancjum), przedkłada on uczestnikom soboru Sudiebnik, do sprawdzenia pod kątem kanonów cerkiewnych, aby ostatecznie potwierdzili oni dokument swoimi podpisami. „Przeczytajcie i zadecydujcie - mówił car - jeśli według was dzieło to jest godne tego, to podpiszcie Sudiebnik i przedstawione razem dekrety. Omówcie i potwierdźcie, zgodnie z regułami św. Apostołów, św. Ojców oraz z wcześniejszym prawem naszych prarodziców" (Glawa IV, Stoglaw, 1862, s. 48-49).

Następnie Iwan IV przeszedł do tematów, dla których zwołany został Sobór - spraw Cerkwi. W tym celu przedstawia on 37 pytań do opracowania na forum Soboru. W pierwszym pytaniu czytamy: „Ojcze mój Makary, Metropolito Całej Rusi oraz wszyscy arcybiskupi i biskupi! Spójrzcie na swoje owczarnie, powierzone wam przez Boga, i pomyślcie o świętych Bożych Cerkwiach, godnych szacunku ikonach i o wszelkim zarządzaniu cerkiewnym, aby w świętych cerkwiach dzwoniono i śpiewano zgodnie z Boskimi zasadami i świątobliwymi regułami. Teraz my widzimy i słyszymy, że liczne cerkiewne obrzędy sprawowane są nie w pełni, nie zgodnie $\mathrm{z}$ regułą cerkiewną i nie zgodnie ze świętymi prawami. Waszym zadaniem jest omówić owe obrzędy i sporządzić zarządzenie zgodnie z Boskimi regułami i świętym prawem w pełni i o całym stanie kapłańskim, mniszym oraz o całej radzie cerkiewnej, i ustanowicie nadzorców kapłańskich nad wszystkimi duchownymi dla zachowania porządku w Cerkwi, ponieważ wam powierzone zostało paść Cerkiew Bożą oraz ustanawiać cerkiewnych urzędników i ich pouczać, abyśmy zbawienie od nich otrzymali, widząc ich dobre uczynki oraz rozwój duchowy" (Glawa V, Stoglaw, 1862, s. 50). W piątym rozdziale postanowień Soboru Stu Rozdziałów przytoczone zostały wszystkie pytania przedłożone przez cara (Stoglaw, 1862, s. 49-76). Cytowany powyżej tekst, jest to „Pytanie 1", ma charakter ogólny. W dalszych pytaniach carskich zostały wskazane bardziej szczegółowe tematy, na które władca pragnie zwrócić uwagę uczestników Soboru.

Ojcowie soborowi omówili wszystkie te zagadnienia i dali na nie swoje odpowiedzi, które zawarte są w rozdziałach od 6 do 40. Obrady soboru przebiegały bardzo owocnie i sprawnie. Jak tylko odpowiedziano na około połowę przedłożonych wcześniej pytań, to car przekazał pod obrady kolejne 32 zagadnienia. Były one nieco krótsze i mniej ważne w swojej tematyce. Odpowiedzi na owe pytania zostały wystosowane od razu. Na każde pytanie dano oddzielną odpowiedź. Wszystkie te pytania oraz wypracowane na nie odpowiedzi zamieszczono w 42. gławie. Następnie prowadzone były dyskusje i przygotowywane były postanowienia związane $\mathrm{z}$ drugą połową przedłożonych pierwotnie trzydziestu siedmiu pytań, jak również tematów, które nie były poruszone w owych zagadnieniach (Kartaszew, 1959, s. 436-437).

Podsumowując historyczny aspekt Soboru Stu Rozdziałów, należy stwierdzić, iż osiągnął swój bardzo uniwersalny cel, a mianowicie poddał on dyskusji różnorodne aspekty funkcjonowania Cerkwi na Rusi, aby doprowadzić do jej oczyszczenia ze wszystkich niedoskonałości. Podczas Soboru powstał szereg przepisów, które w swojej treści odnosiły się do administracji diecezjalnej, sądu diecezjalnego oraz życia duchowieństwa zarówno na wyższym, jak i na niższym szczeblu, a więc mnichów i ludzi świeckich, a w szczególności dotyczyły praktyki liturgicznej, która często była odmienna w poszczególnych diecezjach Cerkwi ruskiej.

\section{Bibliografia}

Anchimiuk, Jeremiasz, abp. (2003). Reformy Patriarchy Nikona. W: Zieniuk, J. (red.), Chrześcijaństwo Kościót Prawosławie. Białystok: Bractwo Prawosławne św. św. Cyryla i Metodego. s. 14-22.

Andrusiewicz, A. (2001). Cywilizacja rosyjska. (T. I). Książka i Wiedza.

Bazylow, L. (2006). Historia Rosji. (wyd. IV). Wrocław.

Bočkarevv, W. A. (1906). Stoglav i istoriâ Sobora 1551 g. Ûhnov. [Бочкарев, В. А. (1906). Стоглав и история Собора 1551 г. Юхнов].

Bulgakov, M. (1870). Istoriâ Russkoj Cerkvi. (T. 6, Kn. I). Sanktpeterburg. [Булгаков, М. (1870). История Русской Церкви. (Т. 6, Кн. I). Санктпетербург].
Čerepnin, L. V. (1978). Zemskie sobory Russkogo gosudarstva $v$ XVI - XVII vv. Moskva. [Черепнин, Л. В. (1978). Земские соборы Русского государства в XVI - ХVII вв. Москва].

Florâ, B.N. (2010). Ioann IV Vasilevič. W: Pravoslavnaâ Enciklopediâ. (Т. XXIII, s. 628-641). Moskva [Флоря, Б.Н. (2010). Иоанн IV Василевич. W: Православная Енциклопедия. (Т. XXIII, s. 628-641). Москва].

Kartašev, A.V. (1959). Očerki po istorii Russkoj Cerkvi. (T. I), Pariž: YMCA-Press [Карташев, А.В. (1959). Очерки по истории Русской Церкви. (Т. I), Париж: YMCA-Press].

Pawłow, A., Perrie, M. (2008). Iwan Groźny car i tytan. Warszawa. 
Sawicki, D. (2012), Dziedzictwo Soboru Stu Rozdziałów oraz rola św. Maksyma Greka w nauczaniu staroobrzędowców -pomorców. Cerkiewny Wiestnik, 1/2012, 37-45.

Sawicki, D. (2013). Idee „Świętej Rusi” i „Trzeciego Rzymu” i ich miejsce w nauczaniu staroobrzędowców pomorskich. Cerkiewny Wiestnik, 1/2013, 47-63.

Serczyk, W.A. (2004). Iwan IV Groźny. Wrocław.

Sinicyna, N.V. (2000). Russkâ̂ Cerkov' v period avtokefalii; učreždenie Patriaršestva. W: Pravoslavnaâ Enciklopediâ. (Т. Russkâ̂ Pravoslavnaâ Cerkov', s. 61-80). Moskva. [Синицына, Н.В. (2000). Русская Церковь в период автокефалии; учреждение Патриаршества. W: Православная Енциклопедия. (Т. Русская Православная Церковь, s. 6180). Москва].

Sinicyna, N.V. (2004). Vasilij III Ioannovič. W: Pravoslavnâa Enciklopediâ. (T. VII, s. 115-122). Moskva. [Синицына, Н.В. (2004). Василий III Иоаннович. W: Православная Енциклопедия. (Т. VII, стр. 115-122). Москва].

Smirnov', I., I. (1944). Ivan Groznyj. Leningrad. [Смирновь, И., И. (1944). Иван Грозный. Ленинград].
Smykowska, E. (2008). Liturgia prawosławna - maty stownik. Warszawa: Verbinum.

Stefanovič, D. (1909). O Stoglave. Ego proishoždenie, redakciâ $i$ sostav. Sankt-Peterbúrg. [Стефанович, Д. (1909). О Стоглаве. Его происхождение, редакция и состав. Санкт-Петербу́рг].

Stempa, T. (2016). Cerkiew prawostawna w Polsce. Warszawa: Warszawska Metropolia Prawosławna.

Stoglav. (1862). Kazan': v Tipografii Gubernskago Pravleniâ [Стоглавъ. (1862). Казань: в Типографии Губернскаго Правления].

Špakov, А., J. (1903). Stoglav. Kiev. [Шпаков, А., Й. (1903). Стоглав. Киев].

Trubačev, A. (2000). Kanonizaciâ svâtyh v Russkoj Pravoslavnoj Cerkvi. W: Pravoslavnaâ Enciklopediâ. (T. Russkaâ Pravoslavnaâ Cerkov', s. 346-371). Moskva. [Трубачев, А. (2000). Канонизация святых в Русской Православной Церкви. W: Православная Енциклопедия. (Т. Русская Православная Церковь, стр. 346-371). Москва].

Tryczyk, M. (2009). Między Imperium a Święta Rosją. Wrocław: Wydawnictwo Novae Res.

Rozmiar artykułu: 0,9 arkusza wydawniczego 
ISSN 1508-7719

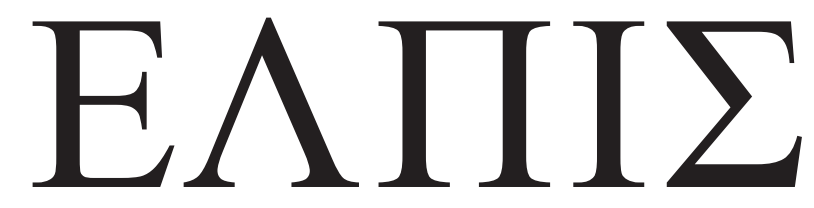

CZASOPISMO TEOLOGICZNE KATEDRY TEOLOGII PRAWOSŁAWNEJ UNIWERSYTETU W BIAŁYMSTOKU

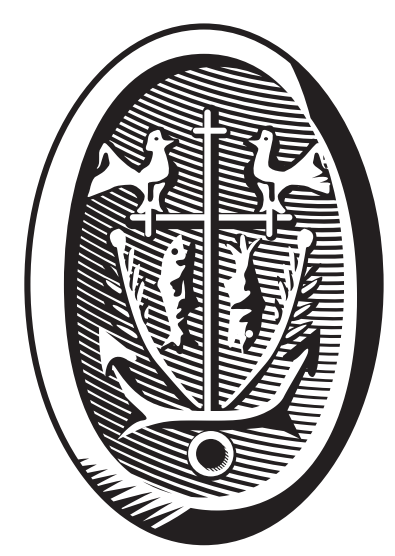

ADRES REDAKCJI

ul. Ludwika Zamenhofa 15, 15-435 Białystok, Polska tel. 85 745-77-80, e-mail: elpis@uwb.edu.pl www.elpis.uwb.edu.pl 